\title{
What explains diversity-policy adoption? Policy entrepreneurs and advocacy coalitions in two French cities
}

\section{Michalis Moutselos}

To cite this article: Michalis Moutselos (2020): What explains diversity-policy adoption? Policy entrepreneurs and advocacy coalitions in two French cities, Ethnic and Racial Studies, DOI: $\underline{10.1080 / 01419870.2020 .1751861}$

To link to this article: https://doi.org/10.1080/01419870.2020.1751861

\section{(c) 2020 The Author(s). Published by Informa UK Limited, trading as Taylor \& Francis} Group

\section{曲 Published online: 29 Apr 2020.}

Submit your article to this journal $₫$

Џ Article views: 185

Q View related articles $\sqsubset$

View Crossmark data $\circlearrowright$ 


\title{
What explains diversity-policy adoption? Policy entrepreneurs and advocacy coalitions in two French cities
}

\author{
Michalis Moutselos
}

Max Planck Institute for the Study of Religious and Ethnic Diversity, Göttingen, Germany

\begin{abstract}
When it comes to public policies that recognize and accommodate ethnic, cultural and religious diversity, cities are active and innovative. However, policy adoption can differ greatly from case to case, with different policy processes leading to different types of instruments across local contexts. This paper focuses on two cases from France, a country usually associated with hostility towards recognizing group-based diversity. In Marseille, there has been a decades-long consensus around group-based multiculturalism. The impetus has come from mayors ("policy entrepreneurs") of both the centreleft and the centre-right. In Grenoble, the uninterrupted dominance of a strong left-wing administration has infused diversity policy with more traditional themes, such as anti-discrimination, universalist participation and civil-society support in the city's stigmatized southern neighbourhoods. The study demonstrates that local-level diversity policy may feature a mix of multicultural, intercultural and universalist elements, and that tracing local policy processes can explain puzzling policy outcomes..
\end{abstract}

ARTICLE HISTORY Received 22 July 2019; Accepted 30 March 2020

KEYWORDS Public policy; diversity; cities; France; policy change; multiculturalism

European city administrations are increasingly developing policy instruments and adopting discourses that target the ethnic, cultural and religious diversity - henceforth "diversity" - of their populations (see, among others, Flamant 2017; White 2017; Martínez-Ariño et al. 2019). Locally implemented policies for the recognition, representation and redistribution of resources favouring previously disadvantaged segments of city populations with a minority background (Vertovec 2012) are coupled with normative and discursive openings towards embracing the image of a diverse or inclusive city (Moutselos et al. 2020). On the heels of policy innovation, policy diffusion assumes the form

\section{CONTACT Michalis Moutselos moutselos@mmg.mpg.de}

(c) 2020 The Author(s). Published by Informa UK Limited, trading as Taylor \& Francis Group

This is an Open Access article distributed under the terms of the Creative Commons Attribution-NonCommercial-NoDerivatives License (http://creativecommons.org/licenses/by-nc-nd/4.0/), which permits non-commercial re-use, distribution, and reproduction in any medium, provided the original work is properly cited, and is not altered, transformed, or built upon in any way. 
of "diversity labels" and networks of "intercultural cities", "rainbow cities" or "cities of migration" (for an overview focussing mostly on networks sharing experiences with integration policies, see Penninx 2015).

Our knowledge about how the introduction of diversity policies takes place in cities, in other words, how, when and under whose auspices policy change occurs or how city officials consolidate a diversity policy framework is gradually becoming more systematic (see, along with special issue, Caponio, Scholten, and Zapata-Barrero 2019). Which diversity policy instruments do local authorities choose to retain for their cities? What types of urban actors among local politicians, administration and civil society actors are involved in their implementation? In addition, as is the case with most policy innovations, the very actors and processes that lead to initial adoption may privilege certain instruments over others; in other words, "diversity policy" may end up assuming different characteristics in different cities reflecting differential ideological orientations, local path dependencies and access to power of different disadvantaged groups. The present paper aims at applying theories of policy adoption and consolidation in cities to the specific case of diversity policy, two fields that have rarely been studied together. It also attempts to situate the empirical analysis of local diversity policy adoption and consolidation in the broader debates about multiculturalism and interculturalism (see Antonsich 2016; Good 2018).

Empirical investigations of this topic suggest that left-wing and centre-left city councils are more likely to introduce policies that accommodate diversity (de Graauw and Vermeulen 2016; Martínez-Ariño et al. 2019 for France), whether to offer ways to combat discrimination or to represent previously disadvantaged groups. However, this view of left-wing politicians as "policy entrepreneurs" (Mintrom and Norman 2009) for consolidating such policies is empirically nuanced by the willingness of many centre-right mayors to consolidate the image of their city as diversity-friendly. Alternatively, successful progressive mayors who do not see the need to change a winning formula by introducing new policies may opt for inertia or incrementalism. I explore here two such seemingly counter-intuitive cases from France: the city of Marseille, where the centre-right city hall has woven the recognition of ethno-religious groups and a "soft" multiculturalism into the fabric of policy and official discourse; and the city of Grenoble, where one of the historically left-wing municipal councils in the country has not emphasized the recognition and promotion of group-based diversity, but resorted to other policy frameworks (universalism, international solidarity, interculturalism) to deal with local diversity.

The lessons drawn from the two case studies are fourfold: First, French cities can be innovative in dealing with the diversity of their populations (see also Martínez-Ariño 2018). Second, in terms of local policy process, French centre-left mayors are likely to instigate change in this field, but the centre-right can choose to sustain policy innovations initiated by the left. 
This explains the puzzling Marseille case. To be sure, a business-friendly view of diversity is more likely to appeal to the centre-right and inform discourse and policy, while social justice for disadvantaged groups may not be equally emphasized. Third, the centre-left in France may introduce policy instruments at the local level, which help, de facto, disadvantaged ethnic, religious and cultural groups, but do not necessarily foreground group-based diversity as a principle of policymaking. As the example of Grenoble demonstrates, a strong progressive policy framework - under conditions of an absence of electoral pressures or a crisis - can develop at the expense of group-specific policymaking. Fourth and relatedly, as historical institutionalists have long argued, local actors are more likely to instigate change when they face some kind of crisis; in the case of Marseille, it was a political and social crisis facing the local socialist party in the 1980s, as well as a rise in interethnic and cultural tensions. Grenoble did not face a similar crisis and the local left-wing mayors did not prioritize group-based policies to appease intergroup relations, but incorporated new "diversity actors" (primarily anti-discrimination activists) in a strong, pre-existing network of local associations.

The next section defines the terms of analysis, including a discussion of diversity policy instruments, and explains in some detail the case selection and data, before laying out hypotheses drawn from theories of the policy process. I then test the hypotheses through case studies of the two cities and finally present conclusions about empirical variation in local diversity policies and lessons about how they are introduced and consolidated at the local level.

\section{Research design, data, definitions, and theoretical expectations}

There is a well-established scholarly consensus that the French state does not recognize groups as the target of public policy, a domain reserved for individual citizens (Simon and Sala Pala 2010, 94-97). However, developments in the last two decades, such as "positive discrimination" based on territory (Blanc 2010) and the institutionalization of measures for gender equality (Bereni 2015) have provided openings for the recognition and restitution of group-based demands. In addition, French lawmakers have passed ever-more sweeping anti-discrimination legislation, which does not target groups, but prejudices anti-discriminatory actions based on assumed group characteristics (Fassin 2002). With regard to discourse, public officials and private actors in France now use the term diversity (diversité) more widely and positively (see Sénac 2012 for a critical overview of developments). These innovations have resulted from initiatives of several disparate actors, rather than the introduction of a new, coherent policy paradigm, but they alter the image of a monolithic "republican" model in French policy-making. 
The research design in this paper operates at two levels, the national and the sub-national. As already noted, France is itself a "least-likely" country case for diversity policy (Rohlfing 2012, 84-88), because it has traditionally been associated with policies ignoring group-based differences. Within France, Grenoble and Marseille are, at least at first sight, two "least-likely cases" for observed policy outcomes because the right-wing city hall in Marseille has implemented group-based policy instruments, while the left-wing city hall in Grenoble has not prioritized such policy instruments. As a comparative case study of subnational variation within one country, the paper aims to highlight local-level processes in policymaking, while holding national-level factors constant; as a congruence analysis of two cases with surprising policy outcomes (Blatter and Haverland 2012, 27-29), it seeks to contribute to hypothesis-testing and an improvement of available explanatory frameworks regarding the introduction of diversity policies in cities. The data used in this article stem from resorting to diverse sets documents, such as political memoires, official statements, reports/announcements issued by the city hall and civil society actors in the two cities, municipal council minutes, local and national newspaper reports and secondary literature on local political histories. The author also conducted field research and semi-structured interviews with politicians, urban planners and civil society representatives in Marseille in June-July 2013. In terms of comparability, Marseille and Grenoble both feature large immigrant populations (around 15 per cent foreign-born in the early-2010s, and above the national average), ${ }^{1}$ a large percentage of which originated from former French colonies in Africa. There is therefore a "functional need" for introducing new programmes and practices (Dobbin, Kim, and Kalev 2011, 387) based on local demographics. Diversity in Marseille is deemed more visible than in Grenoble, because higher shares of immigrantorigin populations from former French colonies inhabit its city centre and because the port city has historically received large migratory waves (Mitchell 2011). However, it is not clear why this visibility should lead to the explicit endorsement of diversity policies or discursive nods towards "communities" - many similarly "diverse" municipalities in Southern France or in the Paris region have not opted for explicitly pro-diversity policy frameworks.

Public diversity policies, which provide a common thread for this special issue, can be defined as "policy instruments aiming to adjust the public administration and its services to a heterogeneous population and to publicly acknowledge the sociocultural diversity of the population" (Martínez-Ariño et al. 2019, 2). They serve to provide the redistribution of resources, recognition of presence, representation in government and provision of public goods that redresses the handicaps historically weighing down certain groups, for instance ethnic, religious and racial minorities, but also sexual minorities (Eisenberg and Kymlicka 2011; Vertovec 2012). At the level of cities this means, in concrete terms and for the purposes of the analysis here policies 
that combine material and discursive elements, such as training and recruitment for the city administration in a way that takes the increasing diversity of the population into account; formal or informal quota rules for the city council; city hall funding for associations explicitly promoting diversity; establishing anti-discrimination offices; the public recognition of previously disadvantaged groups in speeches/public statements, festivals and public spaces.

These policy instruments have been selected because they serve the broader policy functions of administration, service provision, representation and recognition (see also Martínez-Ariño et al. 2019). They complement each other, but may be introduced in waves and implemented gradually. They combine elements of group-based multiculturalism, for instance in terms of targeted recruitment at the local administration, or recognition in public spaces, but they also include "intercultural" policy instruments, for instance in promoting broader diversity training, protecting rights of individuals of diverse backgrounds and providing opportunities for interaction in public spaces, for instance in festivals and inter-religious forums (see Antonsich 2016). It is, however, important that such policies are explicitly targeting individuals or groups on the basis of ethnic, religious or otherwise diverse cultural background, so any redistributive policies (for instance through schooling, transportation or housing policy) that have an indirect impact on these segments of the populations are not included in the analysis here. Furthermore, my focus is on policies that fall under the competences of city administrations and do not simply reflect the implementation of national laws and directives.

French cities are increasingly interested in such policies. In 2011 a study conducted in twelve large cities (Marseille and Grenoble were not included) showed that many French mayors actively engage in some kind of diversity policy-making, as defined and operationalized above. For instance, they appoint adjunct mayors in charge of a related portfolio, take actions to combat discrimination, organize events that inform citizens about diversity issues, and help religious associations in their handlings with the city administration (although no funding is provided) (Association des Maires de grandes villes de France 2011). This trend is particularly visible in cities that are historically left-wing or have had a progressive mayor for a long period, such as Rennes, Lille, Lyon, Montpellier and Nantes (Bereni and Epstein 2015; Martínez-Ariño 2018; Flamant this special issue). Many of them have adopted a specific strategic choice to present themselves as "diversity-friendly".

Why would French cities innovate in the diversity field? A canonical literature on the policy process offers explanations for the adoption (or lack thereof) and eventual consolidation of diversity policies. The "multiple streams" theory of policy change (Kingdon [1984] 1995) introduces the idea of the "policy entrepreneur" who aligns a problem stream - a specific interpretation of an existing problem in the public realm -, the policy 
stream - concrete policy instruments that offer a solution -, and the politics stream - the political coalition necessary to implement policy change. In the case of diversity policies in French cities, the empirical implication is that progressive activist mayors with disproportionate agenda-setting power act as the "policy entrepreneurs", exploiting windows of opportunity to "surf" on a salient problem and provide their preferred policy solutions (Boscarino 2009). Policy entrepreneurs are also likely to introduce new policy paradigms by turning their cities into nodes of "policy diffusion" from other cities or levels of government (Berry and Berry [2007] 2018). Indeed, French mayors are generally regarded to be powerful compared to their European counterparts, and studies of local policy-making show that they are instrumental in agenda-setting and problem-definition (Borraz 1998; Cadiou 2013). In the cases of Marseille and Grenoble, we should observe activist mayors initiating change in the former, and the absence thereof leading to policy stasis in the latter.

An alternative framework for explaining policy outcomes is the "advocacy coalition" framework (Sabatier and Weible 2007), which emphasizes the shared core beliefs of coalitions of actors, often described as "subsystems". These coalitions are relatively stable over time and the opinions of actors forming them are homogeneous, but they are also rather autonomous from political decision makers. Policymaking is thus fragmented and relies on specialized information these actors possess, while policy change is incremental, requiring shifts in deeply entrenched beliefs or external imposition (Pierce et al. 2017, 16-18). The advocacy coalition framework does not allow as much room for opportunistic behaviour on the part of powerful actors (like mayors in the context of cities) as the multiple streams framework. To the extent that city-level policymaking in France has evolved towards a model of fragmented governance through differentiated policy networks (as argued in Le Galès 2001), the advocacy coalition framework seems fitting for explaining the incremental adoption or even absence of diversity policy instruments, as we see in Grenoble. It can also mean, however, that right-wing mayors refrain from major policy changes against core tenets of an entrenched advocacy coalition.

A third explanatory framework of the policy process focuses more on the pace of change and less on the actors responsible for it. Punctuated equilibrium theory (Baumgartner and Jones 2010) posits that policy adoption happens in short periods of rapid change, after a long period of inertia in which existing institutions and policy actors have exercised policy modifications only incrementally, if at all. When change does happen, it is because pre-existing "policy images" and "policy venues" are challenged under the weight of cumulative "positive feedback" for alternative policy frameworks; at the same time, the attention of main actors turns to the issue for a brief period where rapid change becomes possible. A related idea is that of a 
critical juncture (Capoccia and Kelemen 2007) whereby choices of individual actors in relatively short periods of time have great consequences for the choices available to future actors. Punctuated equilibrium theory can be complementary to the two aforementioned frameworks in explaining policy change (in this case the adoption of diversity policies). Punctuated equilibria or critical junctures, for instance, during a major local crisis, provide openings for policy entrepreneurs and initiate rapid learning for advocacy coalitions.

To summarize the empirical implications for the study of diversity policies in the two puzzling cases of Marseille and Grenoble: actors initiating drastic policy change are likely to be entrepreneurial, progressive mayors (Marseille), while members of an established "advocacy coalition", are likely to avoid major policy shifts and pick policy instruments that conform to established core policy ideas (Grenoble). With regard to the pace of change and adoption of diversity policy instruments, they are likely to accelerate following a "punctuated equilibrium" or "critical juncture", when structural and institutional conditions are in flux, creating an opening for the kind of progressive, prodiversity mayor who is likely to promote a corresponding pro-diversity policy agenda.

\section{Marseille: city-hall directed multiculturalism}

The Southern port city of Marseille is well-known for publicly embracing the diversity of its population and as a historical meeting point of people of various origins (Mitchell 2011; Ambrosini and Boccagni 2015; Downing 2015). In terms of specific policies and discursive openings initiated by the city hall towards the diversity of its population, one can single out the Marseille Espérance, a city-hall-led initiative that gathers religious leaders to diffuse tensions in times of local or national crisis, as well as the sculpture monuments associated with it featured in the city's public spaces; a relatively robust presence of council representatives of immigrant origin explicitly courting a "community vote" already since 1989; public city hall support over the years for the building of a Marseille mosque; several discursive nods to the benefits of diversity in Marseille by mayors and local politicians, as well as references to its cosmopolitan past and the city's "communities". In 2013, in an example of many references to local diversity over the years, centre-Right mayor Jean-Claude Gaudin, wrote that "Marseille is the city of diversity. A diversity that is cultural, ethnic, religious. Our co-citizens experience it daily in a spirit of openness and dialogue. It is an opportunity and an advantage for our city". 2

Urban actors from Marseille publicly and consistently mention its diversity, multiculturalism, welcoming culture and ability to mix populations of different origins as one of the city's relative strengths. It is also notable that the city's local prosecutors regularly inform Marseille's religious leaders of judicial 
investigations of racist incidents, a portfolio to which French anti-racist and anti-discrimination groups usually enjoy privileged access. ${ }^{3}$ Municipal policymaking with specific communities as targets is also reflected in mobilization before elections. If Cesare Mattina has convincingly demonstrated the selection of Armenian and Jewish candidates to represent their groups in Marseille politics over decades (Mattina 2016, 238-246), there is evidence that such practices have been gradually extended to the city's African and Muslim communities. Comorian candidates on the Left and the Right have explicitly campaigned for the Comorian vote, the most recent and perhaps poorest immigrants to arrive in Marseille in the last decades (Baquey 2013). Socalled "Muslim candidates" have also been included in electoral lists of both Left and (centre-) Right parties at increasing rates over the last twenty years. Their campaigns have explicitly targeted the needs of the city's Muslims often in relation to the Grand Mosque project, even though the existence of a meaningful Muslim voting bloc remains disputed (Geisser and Kelfaoui 2001; Lorcerie and Geisser 2011, 228-236).

The city of Marseille thus exercises diversity policy using several of the policy instruments mentioned in the introduction: it recognizes the importance of diversity in the city population and allows for the participation and representation of ethnic and religious groups at the municipal council, as well as other policy fora. As we shall see, in some detail later in this section, the city also provides extensive funding for ethnic and religious associations. How did such explicit group-based diversity policy come about? The institutional breakthrough that Espérance exemplified, as well as other related policy innovations can be traced back to a crisis in the 1970s and early 1980s that had stigmatized the city nationally as a hotbed of racism. Incidents that contributed to this trend were several murders of North-African workers, the bombing of the Algerian consulate resulting in four dead and several injured, vandalisms against Jewish establishments and cemeteries and the rise of the local Front National (Lorcerie and Geisser 2011, 253-256). In addition to what could be described as a postcolonial crisis, the city was going through a severe economic downturn that saw the clientelist system of the septuagenarian Socialist mayor Gaston Defferre unravel (Peraldi and Samson 2013, 81-91).

In this context, Robert-Paul Vigouroux, a relative outsider in Marseille politics, was able to form a new political alliance that included progressive leftwing and centrist politicians. He was first elected mayor under the banner of the Socialist party succeeding Defferre who died in office in 1986, and then was reelected as an independent candidate in 1989. With regard to managing the ethnic, cultural and religious diversity of the population and besides founding Marseille Espérance in 1990, Vigouroux made explicit overtures to the city's religious and immigrant organizations, in an effort to replace Defferre's politics of clientelistic favouritism with elements from the 
city's civil society. In his book outlining his vision as mayor, Vigouroux explicitly endorsed ethnic community associations for purposes of swift integration of immigrants into the French society and called France a "multicultural society". He concluded that "the role of elected officials is to give them [associations of foreigners] a chance to build bridges with one another" (Vigouroux 1991, 114-116). Vigouroux also specifically addressed ethnic and religious communities qua minorities, as opposed to as transient immigrants, transforming them into actors in the local political process. He argued publicly that his electoral lists reflected community-based representation and named a cabinet official as responsible for relations with the Marseille "communities" (Cesari 1994, 72-73).

Vigouroux' activism in institutionalizing group-based policies and a discursive multiculturalism shows that Marseille's present policies originated from a left-wing political coalition, as is commonly thought (Martínez-Ariño et al. 2019). Marseille's early adoption of a multiculturalist policy framework is also explained by combining the punctuated-equilibrium and "multiplestreams" theories of policy change. The severe community-relations and economic crises that overwhelmed the city during the decade leading up to his mayoral term can be described as a classic "problem stream" to which Vigouroux proposed the "policy stream" of community recognition and group-based representation as a solution. Acting as an innovative policy entrepreneur he presented the crisis of clientelism in the city as an opportunity for privileging civil society, in which ethnic communities and their associations played an organic part. His progressive coalition succeeded in aligning the problem and proposed solution with the "politics stream" by directly challenging the candidate supported by the Socialists in 1989 and eventually carrying the municipal elections.

When the centre-Right candidate Jean-Claude Gaudin beat Vigouroux and the Socialist-party candidate in 1995 to become the new mayor, he faced a dilemma between dismantling the multiculturalist framework of his predecessor and continuing it with some revisions that would befit his more conservative coalition. A previous agreement with Front National regional councillors made it plausible that Gaudin would steer city politics towards the right, under pressure from Marseille's ever-strong extreme Right. ${ }^{4}$ Perhaps the real puzzle is why Gaudin opted for a more centrist path in his relations with Marseille's communities and retained the policies, discourse and institutions of his predecessor. Indeed, the centre-right mayor endorsed and presided over Espérance, placed candidates of immigrant origin on his electoral lists, supported Marseille's Grand Mosque (which was eventually not completed for lack of financing), funded public parades celebrating the city's diversity (such as the parade Marsilia in 1999), and adopted the discourse of community coexistence and multiculturalism, as the quote in this section's opening paragraph demonstrates (see also Gastaut 2003; Lorcerie and Geisser 2011, 58). 
Gaudin's retention of diversity policies can be explained through the prism of the advocacy coalition framework. Not facing a crisis similar to the one that brought Vigouroux to power, Gaudin operated with the pre-existing, established actors/policy networks in this field he inherited from his predecessor (in this case, Marseille's religious and ethnic community leaders). Acting within this policy framework, Gaudin opted for incremental changes, rather than a complete overhaul in what can be described as an example of "paradigmatic pragmatism" (Schiller 2015): he cultivated personal relations with the representatives or the regional council of Muslim faith (CRCM) and provided its offices at Marseille's city centre, partly in order to combat the extreme fragmentation among the city's Muslims. Gaudin's city hall also continued to distribute funds for ethnic and cultural associations in many of Marseille's neighbourhoods, leading to a sort of community-based clientelism (Moore 2001). One can argue that Gaudin added new policy framings of diversity and new actors to pre-existing policy networks, which suited his coalition better, but did not alter the core tenets of the pro-diversity advocacy coalition formed during the Vigouroux years. Besides moderate Catholic leaders that supported the initiatives of religious dialogue and funding implicitly targeting religious groups, the local centre-Right in Gaudin's coalition courted probusiness networks that sought to benefit from the image of a multicultural metropolis. As a result, large projects aiming at revitalizing the city, such as the reconstruction of a neighbourhood near the port and the candidacy for the European capital of culture, and tourist campaigns aimed at wealthy international visitors made specific references to the dynamism stemming from the city's diversity and multiculturalism. ${ }^{5}$

This kind of policy, which combines preferential treatment for ethno-religious groups and a commercial use of the diversity discourse is not without critics. In a masterful treatment of urban clientelism in Marseille, Mattina (2016, 238-290) has argued that the city hall practices a very uneven distribution of symbolic and material resources among these recognized communities. On one side there are winners: Armenians, Jews and the French repatriated from Algeria, who receive recognition, political support and subsidies; and on the other side there are clear losers, namely the Maghrebi and Comorian communities. In addition, an implicit group-based attribution of social housing leads to spatial segregation in the city. In 2013 the adjunct mayor in charge of municipal policies against exclusion blamed "clientelist policies inherited from past administrations" for the geographic concentration of populations of non-European immigrant origin in Marseille's 13th, 14th, 15th and 16th arrondissements. ${ }^{6}$ Mattina, his critique of the distributive outcomes of such policies notwithstanding, confirms that municipal practices with regard to funding ethnic and religious associations lead to a further "hardening" of ethnic groups in Marseille (2017, 283-288, see also Césari 1993, 90-92). 
In addition, Marseille mayors explicitly use group-based "diversity" policy and in particular Espérance for social control, that is, to avoid conflicts (often of a violent nature) between members of the city's communities, for instance in the wake of the 2005 Paris attacks. Thus diversity policy is in this case considered as preventative and contributing to peace, reflecting the more extreme circumstances in which the policy framework was first adopted by Robert Vigouroux. At the same time, and in comparison to other French cities, the city of Marseille does not have consolidated policies that combat individual instances of racism and discrimination through training of city officials, administrators of the politique de la ville, educators and municipal police on related issues. ${ }^{7}$ Anti-discrimination measures are, of course, one important dimension of diversity policies, if perhaps the most conventional and least innovative, with their emphasis on individual cases, they are less suited for a group-based policy framework, such as the one practiced in Marseille. The pro-diversity policy framework is very different in the case of Grenoble.

\section{Grenoble: a progressive city with a conservative approach to diversity}

Grenoble, a prosperous city at the foot of the French Alps, is well-known in France as a bastion of progressive politics and prides itself in a long-standing democratic socialist tradition, starting in the 1960s with iconic mayor Hubert Dubedout (Frappat and Dubedout 2016). The progressive coalition of Grenoble has historically combined the clout of economically outward middle-class professionals, non-Communist trade unions and "new left" ecologists, in what is known as the "Grenoble model" or "myth" (Bruneteau 1998). The city's emphasis on high-technology innovation and its dynamism can be contrasted with Marseille's long-term struggles with economic stagnation. Consequently, the city has not faced a crisis of economic or inter-ethnic tensions similar to Marseille.

Interestingly, the city's narrative of success does not encompass ethnic, religious or cultural diversity, the recognition of communities or group-based policymaking, as it does in Marseille. As I show below, Grenoble's urban actors have been very cautious to mention ethnic or cultural mixing as a source of the city's dynamism and focus instead on its innovation-driven economic prosperity, geographic location, and strong network of local associations. No specific initiative like the Marseilles Espérance has emerged as the focal point of community relations in the city. Diversity, when it appears in official discourse, is typically described as a synonym for the international outlook of the city's companies and universities, in a standard reiteration of the business case for diversity that focuses on skills and creative lifestyle (Florida 2005; Page 2007). 
Mayoral speeches and programmatic statements from Grenoble's recent past have similarly lacked discursive nods to diversity, indicating that successive progressive mayors have not acted as policy entrepreneurs in this new field. For instance, Eric Piolle, the mayor elected in 2014 under the banner of a Left-Green coalition that seems peculiar to Grenoble's progressive politics, devoted no words to specific ethnic or religious communities of the city, the diversity of its population and instruments to recognize or represent it in his 120 programmatic positions. The programme was otherwise full of innovative ideas about local democracy, environmental sustainability and the duties of councillors vis-à-vis their citizens. ${ }^{8}$ Piolle's predecessor wrote an entire book about his legacy as a twenty-year-long Socialist mayor of Grenoble; the book is marked by a similar absence of any references to diversity or ethnic-religious communities (Destot 2015). This absence is all the more striking, if, as already noted in the introduction, one considers the relatively high numbers of immigrants in the city that are comparable to Marseille (16 per cent in 2013, with about half of them of North- and Sub-Saharan African origin).

Along with the absence of discursive or symbolic overtures towards the diversity of the population, and in contrast with Marseille, Grenoble's political factions also do not mobilize the "community vote". To be sure, many councillors of African origin have been elected to the city council over the years, but there is no evidence of explicit mobilization or publicly stated representation of specific ethnic or religious communities. The public biographies of present and former councillors with non-European immigrant background paint the picture of a progressive city council with a high emphasis on classic left-wing themes, like social and international solidarity. Some examples that stand out are: Salima Djidel (progressive activist), Sonia Yassia (responsible for the realization of small-size projects in the Villeneuve neighbourhood), Sadok Bouzaiene (former political exile from Tunisia) and the former council in charge of fighting discrimination, Linda El-Haddad (director of Grenoble's SOS-Racisme branch). ${ }^{9}$ Still, in their biographies and other public interventions these immigrant-origin councillors do not claim to represent a specific ethnic/religious group, unlike their Marseille counterparts.

The silence surrounding multiculturalism in Grenoble can also be observed in a recent special issue of the municipal magazine, entitled "Grenoble: place of welcome" (terre d'accueil). In the text, an initial emphasis on "internationalization since the great industrial migrations" quickly shifts to the present international orientation of the city for foreign students and researchers. ${ }^{10}$ The North-African populations of the city are celebrated exclusively in connection with earlier generations who arrived in the 1960s to build the venues of the Winter Olympic Games. Tellingly, in a 2008 speech named "Solidarity in a multicultural society" in Grenoble, former Minister of Culture Catherine Tasca 
recognized the importance of past immigration from Italy and the Maghreb for the city, but tied local practices of intercultural exchange to more conventional neighbourhood policies (for instance in the neighbourhood of Villeneuve) and the cultural offerings at the Maison de la Culture. ${ }^{11}$

Tasca's comments are symptomatic of a general pattern: diversity policy in Grenoble is inflected through established, progressive policy frameworks that emphasize non-discrimination, solidarity and, to a lesser extent intercultural exchange. Gradual introduction of diversity policy instruments rests on an entrenched advocacy coalition that consists, as a first part, of members of the local administration involved in policy fields presumed of direct importance to immigrants and their descendants (for instance, cultural or housing policy). If Marseille officials and civil society actors openly consider problems and solutions in their city as inter-communal, their counterparts in Grenoble are concerned about the social segregation in their city, exacerbated by features of its urbanistic characteristics. The Southern suburbs, including the aforementioned Villeuneuve neighbourhood, suffer from socio-spatial inequality and a sense of lack of security. They are targets of city-level and national "politique de la ville" and combine high unemployment rates, a large share of persons of immigrant origin (in some of them surpassing 30 per cent) and a large percentage of social housing units. Therefore, Grenoble should not be considered an interethnic heaven. In many ways, the city has not escaped the nation-wide pattern of tensions in its banlieues: in 2005, 2010 and 2019 riots erupted between the police and local youth following perceived police brutalities.

There is, in addition to established politique de la ville actors, a second part of Grenoble's established advocacy coalition that pushes for gradual change in the local diversity policy framework: anti-racism or anti-discrimination associations. Their centrality among the city's urban actors and strong ties with the city hall would make it misleading to characterize Grenoble as neglectful of diversity issues. In particular, policy instruments with regard to anti-discrimination are abundant. Grenoble's adjunct mayor of Equality of Rights is in charge of overseeing actions and policies against racism in the city, while the administration has, over the years, harmonized its approach against discrimination with other regional and national state actors, such as the Défenseur des Droits. ${ }^{12}$ By way of comparison, Marseille only instituted an adjunct mayor responsible for anti-discrimination in 2014, following a well-publicized campaign by the Representative Council of Black Associations (CRAN). ${ }^{13}$ Grenoble has also always been at the forefront of progressive causes with regard to asylum-seekers, refugees and undocumented immigrants. Many associations advocating the rights of such groups are funded by the city hall and house in the House of Associations (Maison des Associations). Grenoble has additionally strived to integrate its immigrant population, especially those without formal rights, into municipal governance structures. In the spirit 
of civic universalism and intercultural exchange, it encouraged, already since 2000 , the participation of foreign residents in neighbourhood councils, coordinated pro-immigrant associations in the follow-up of the 2015 asylum crisis and created a mentorship programme for the city's irregular migrants. ${ }^{14}$ Otherwise, the city hall provides brochures and other public documents in a number of languages and has funded, according to the municipal magazine, as many as 110 African organizations for activities "that resonated with current events". ${ }^{15}$

Summarizing, one can argue that Grenoble's municipal council followed a strategy that emphasized anti-discrimination measures and the support of associations dedicated to the issue of racism, discrimination, universalist "equality of treatment". The municipal councillor responsible for the "fight against discrimination and for Human Rights", Linda El Haddad, constituted a municipal plan in 2010, with the 3-pronged goal of training municipal employees, providing help to Grenoble citizens that were victims of discrimination and funding the relevant associations. ${ }^{16}$ In this sense, Grenoble is a good example of the process of institutionalizing and prioritizing anti-discrimination policies at the city level and across various municipal policy fields (employment, housing, schooling, culture) as described by Debenedetti (2018, 141-172). It is no coincidence that in 2015 the city applied to obtain a "Diversity Label", in an effort to gain outside recognition of its initiatives in the field of anti-discrimination.

Through the prism of these established policy frameworks (politique de la ville, anti-discrimination policies) that incorporate aspects of the city's diversity, but do not challenge core tenets of longstanding advocacy coalitions, the Grenoble case is no longer puzzling. In the absence of any major crisis, the city has continued to do what it is famous for - namely progressivism through strong neighbourhood-level associations, but with no elevated privileged role for ethnic or religious community representatives. Take for instance the central role assigned by the city hall to the Consultative Council of Foreign Residents of Grenoble (CCREG) and the Observatory of Discriminations and Intercultural Areas (ODTI). These associations are mentioned by Grenoble urban actors as key representatives of the interests of immigrant populations and their names appear regularly in coordinating initiatives of the city hall. ${ }^{17}$ Their founding can be traced back to the rich associational milieu of the city, and they have enjoyed full support of the city hall. Their expansion of duties happened gradually and in the follow up of external crises (such as the recent refugee crisis) to which the city responded with a typical call for solidarity. Their character fits better with a policy framework that emphasizes universal rights to participation (CCREG) and intercultural understanding (ODTI), as principles of living in local diversity, but avoids group-based advocacy.

When Grenoble did experience an internal crisis, which could have been construed as a "problem stream" of inter-communal relations, the Grenoble 
mayors, the possible instigators of entrepreneurial innovation, turned, again, to established policy frameworks and networks to offer solutions. In July 2010 the suburb of Villeneuve was affected by three days of violent rioting, following the death of a local youth who had been chased by the police. The event assumed national importance because of a speech by the then President Nicolas Sarkozy (heretofore cited as the divisive "Grenoble speech") who tied the riots to failures of immigration and integration. The response of the then Socialist mayor Destot avoided a security-based approach or any mention of group-based local grievances, but was otherwise typical of wellestablished policy solutions of the French Socialist party nationally and locally. His team devised a 3-year plan for Villeneuve promising more local jobs, more money for neighbourhood associations, a plan for urban renovation and more policing. The plan included no policy considerations for mending local community relations or local perceptions of discriminatory state institutions, such as the police. ${ }^{18}$ The city hall document actually reflected the positions and policy frames of local associations from the Villeneuve associational milieu, the latter having officially demanded more funding for their existing neighbourhood activities ("education", "dialogue with the youth", "living together") in a "white book" towards the mayor. ${ }^{19}$

\section{Discussion and conclusions}

The comparison between municipal policymaking in Marseille and Grenoble with regard to ethnic, religious and cultural diversity reveals two different approaches in how these types of policies are introduced and consolidated. Marseille's multiculturalism features an entrepreneurial mayor, Robert-Paul Vigouroux, who introduced principles of community/group-based policymaking in a moment of crisis; and a second mayor, Jean-Claude Gaudin, who inherited this policy framework and adapted it to the needs of his electoral coalition. Thus, despite the persistence of inequalities among ethno-religious groups, diversity recognition and representation in Marseille can be described as more group-based, top-down, explicit in terms of symbolic recognition, and, geared towards inter-communal peace. Ethnic and religious associations are major interlocutors with policymakers and members of the city council act as community representatives. During the initial phase of policy adoption (the Vigouroux period) the Marseille case fits better the punctuated equilibrium and multiple streams framework; during the later phase of policy consolidation under Gaudin the advocacy coalition framework better explains policy continuity and the less radical innovations introduced to the city's community-based multiculturalism.

Grenoble, on the other hand, has, for a long time, featured progressive mayors, such as Michel Destot and Éric Piolle, who inherited a robust, uninterrupted city tradition of policymaking based on a neighbourhood-level, 
progressive civil society. Innovations in the field of ethnic, cultural and religious diversity have been incremental and introduced as additions to the pre-existing associational milieu of the city. Local associations and experienced local policymakers in the fields of the politique de la ville and anti-discrimination policy are the major actors in local networks of policy-making. In the meantime, the lack of any crisis in inter-communal relations has prevented radical shifts, such as the introduction of group-based policy or discursive multiculturalism. The kind of incremental change within established leftwing policy networks in Grenoble fits better the advocacy coalition framework. This incrementalism has not prevented the city from positioning itself at the vanguard of pro-refugee and anti-racism or anti-discrimination struggles and from adopting less group-specific diversity policy instruments, such as diversity training.

The article has broader implications for the study of the policy process in the field of diversity policy in cities. It shows that diversity policy instruments can look very different depending on whether group-based demands and representation are recognized as the basis of public discourse and public policy (as is the case in Marseille). Alternatively, municipal policy may be based on broader principles of solidarity and anti-discrimination; in which case intermediation with the city hall and representation of diversity may materialize through more established channels among the city administration or through a progressive associational milieu (as is the case in Grenoble). Differing diversity policies in the two cities demonstrate empirically how multicultural and intercultural policies work at the local level (Good 2018; ZapataBarrero and Cantle 2019). Grenoble's approach can be thought of as a combination of traditional civic universalism and interculturalism, because the city does not target specific groups, but provides spaces, resources and opportunities for the protection against discrimination and for the expression of intercultural understanding at the neighbourhood level. Marseille, on the other hand, has adopted more of an openly multicultural approach, even if some of its initiatives can be considered intercultural (for instance, the city parades, and the interaction among religious leaders in the context of Marseille Espérance). As already noted, the two cities do not constitute "ideal types": anti-discrimination measures are more developed in Grenoble, while Marseille's centre-right ruling coalition often uses local multiculturalism pragmatically, to promote an image of a globally open city (see Schiller 2015, 1126 for a similar analysis). In any case, it is fascinating that such empirical variation is found in a country like France, with its supposedly monolithic approach to citizenship-based public policy. The article also argues that local policy frameworks are "sticky", as has long been argued by scholars studying national-level policy frameworks. A centre-right mayor, such as Jean-Claude Gaudin, found it more convenient to continue rather than dismantle the apparatus in the field of diversity, created by his predecessor. Similarly, Grenoble mayors are 
constrained to consult and cooperate with powerful established actors in the city administration and civil society, and the policy outcomes reflect these constraints.

\section{Notes}

1. "Etrangers et immigrés en 2012, Commune de Marseille". Accessed May 15, 2019, https://www.insee.fr/fr/statistiques/2130578?geo=COM-13055. "Etrangers et immigrés à Grenoble" Accessed February 2, 2019, https://www.adesgrenoble.org/wordpress/2017/01/13/etrangers-et-immigres-a-grenoble/

2. Programme of the third Regional Biennale on "History, Memory, Immigration, Territories" (2015), Introduction by mayor Jean-Claude Gaudin. Available at: https://www.scribd.com/document/279389387/3e-biennale-Histoire-Memoiredes-Immigrations-et-Territoires-en-PACA

3. Commission Nationale Consultative des Droits de I'Homme (2014), La Lutte contre le Racisme, l'Antisémitisme et la Xénophobie: 368.

4. Le Monde, "À Marseilles, I'Ogre Gaudin", September 28, 2013.

5. Indeed Gaudin launched the official candidacy of Marseille as the European capital of culture for 2013 by representing it as a "mosaic city, that is, for centuries, a symbol of exchanges among civilizations, through the diversity of communities that constitute it and the cultural currents that nourish it". See Ville de Marseille (2006).

6. "Lutte contre le Racisme: pourquoi Marseille est mal noté". Metronews, December 4, 2013.

7. Baromètre contre le Racisme. Classement des Villes de France en matière de lutte contre le Racisme. Accessed February 2, 2019. http://www.le-cran.fr/ document-cran-associations-noires-de-france/71-barometre-des-villes-contrele-racisme.pdf.

8. "Grenoble, Une ville pour tous". Accessed January 25, 2019, http://unevillepourto us.fr/wp-content/blogs.dir/839/files/2014/02/ProjetGrenobleUneVillePourTo us.pdf

9. Biographies for Djidel, Yassia and Bouzaiene found at http://unevillepourtous.fr/ elus, accessed May 16, 2019; biography for Linda El-Haddad found at http:// www.poteapote.com/Portrait/Linda-El-Haddad, accessed May 16, 2019.

10. GRE-MAG, Le Magazine de la Ville de Grenoble, 2016 (12), 17.

11. "La solidarité dans la société multiculturelle", speech by Catherine Tasca, 1st National Convention, Inventer à Gauche.

12. See Emmanuel Carroz, "Grenoble lutte contre toutes les discriminations". comments at municipal council, 21 March 2016.

13. Baromètre contre le Racisme. Ibid.

14. Ibid., 18.

15. GRE-MAG, Le Magazine de la Ville de Grenoble, 2016 (8), 42.

16. Plan Municipal de Prévention et de Lutte contre les Discriminations: Billan et Perspectives accessed May 15, 2019, https://www.grenoble-ensemble.fr/tribuneset-analyses/plan-municipal-de-prevention-et-de-lutte-contre-les-discriminationbilan-et-perspectives/.

17. For the history and functions of CCREG, see "Conseil Consultatif des Résidents Etrangers Grenoblois", accessed February 2, 2019. For the current role of ODTI in the refugee crisis, see "Aide aux réfugiés: la plateforme de coordination est 
en place" in "Grenoble, Terre d'Accueil", Gre.mag, Accessed February 3, 2019, at http://www.gre-mag.fr/actualites/aide-aux-refugies-la-plateforme-decoordination-est-en-place/

18. Municipal council minutes, City of Grenoble, April, 18, 2011. See also Le Point, July 7, 2011. "Un an après les émeutes de Grenoble" accessed March 6, 2019 at https://www.lepoint.fr/societe/un-an-apres-les-emeutes-de-grenoble-20-072011-1354677_23.php

19. Collectif Inter Associations de la Villeneuve, January 11, 2011. "Le Livre Blanc".

\section{Disclosure statement}

No potential conflict of interest was reported by the author(s).

\section{ORCID}

Michalis Moutselos (D) http://orcid.org/0000-0002-8454-1124

\section{References}

Ambrosini, Maurizio, and Paolo Boccagni. 2015. "Urban Multiculturalism Beyond the 'Backlash': New Discourses and Different Practices in Immigrant Policies Across European Cities." Journal of Intercultural Studies 36 (1): 35-53.

Antonsich, Marco. 2016. "Interculturalism Versus Multiculturalism - The Cantle-Modood Debate" Ethnicities 16 (3): 470-493.

Association des maires de grandes villes de France. 2011. Étude politique de la ville: la diversité dans les grandes villes, un enjeu majeur pour les élus. Online publication 16 November. http://franceurbaine.org/espace-presse/communiques-de-presse/ etude-politique-de-la-ville-la-diversite-dans-les-grandes-villes.

Baquey, Cécile. 2013. "Municipales à Marseille: quelle représentation pour les Mahorais et les Comoriens?" France Info, Outre-mer la Première. December 6.

Baumgartner, Frank R., and Bryan D. Jones. 2010. Agendas and Instability in American Politics. Chicago: University of Chicago Press.

Bereni, Laure. 2015. La bataille de la parité. Mobilisations pour la féminisation du pouvoir. Paris: Economica.

Bereni, Laure, and Renaud Epstein. 2015. "Instrumenter la lutte contre les discriminations: le «label diversité» dans les collectivites territoriales." Diss. CNRS-Centre Maurice Halbwachs; Université de Nantes-Droit et Changement Social.

Berry, Frances Stokes, and William D. Berry. (2007) 2018. "Innovation and Diffusion Models in Policy Research." In Theories of the Policy Process, edited by Christopher M. Weible and Paul A. Sabatier, 263-308. New York, NY: Routledge.

Blanc, Maurice. 2010. "The Impact of Social Mix Policies in France." Housing Studies 25 (2): 257-272.

Blatter, Joachim, and Markus Haverland. 2012. Designing Case Studies: Explanatory Approaches in Small-N Research. Basingstoke: Palgrave Macmillan.

Borraz, Olivier. 1998. Gouverner une ville: Besançon, 1959-1989. Rennes: Presses Universitaires de Rennes.

Boscarino, Jessica E. 2009. "Surfing for Problems: Advocacy Group Strategy in US Forestry Policy." Policy Studies Journal 37 (3): 415-434. 
Bruneteau, Bernard. 1998. "Le 'mythe de Grenoble' des années 1960 et 1970. Un usage politique de la modernité." Vingtieme siecle. Revue d'histoire 58 (2): 111-126.

Cadiou, Stéphane. 2013. "Jeux et enjeux de connaissances. L'expertise au service de la gouvernance municipale." In La gouvernance territoriale. Pratiques, discours et théories, edited by Simoulin Vincent, and Pasquier Romain, 197-221. Paris: LGDJ.

Capoccia, Giovanni, and R. Daniel Kelemen. 2007. "The Study of Critical Junctures: Theory, Narrative, and Counterfactuals in Historical Institutionalism." World Politics 59 (3): 341-369.

Caponio, Tiziana, Peter Scholten, and Ricard Zapata-Barrero, eds. 2019. The Routledge Handbook of the Governance of Migration and Diversity in Cities. New York, NY: Routledge.

Césari, Jocelyne. 1993. "Les Leaders Associatifs Issus de L'immigration Maghrébine: Intermédiaires ou Clientèle." Horizons Maghrébins - Le Droit à la Mémoire 20 (1): 80-95.

Cesari, Jocelyne. 1994. "Marseille face à ses communautés." Esprit 202 (6): 66-77.

de Graauw, Els, and Floris Vermeulen. 2016. "Cities and the Politics of Immigrant Integration: A Comparison of Berlin, Amsterdam, New York City, and San Francisco." Journal of Ethnic and Migration Studies 42 (6): 989-1012.

Debenedetti, Marie-Christine Cerrato. 2018. La lutte contre les discriminations ethnoraciales en France: de l'annonce à l'esquive (1998-2016). Rennes: Presses universitaires de Rennes.

Destot, Michel. 2015. Une Passion for Grenoble. Paris: Editions de l'Aube.

Dobbin, Frank, Soohan Kim, and Alexandra Kalev. 2011. "You Can't Always Get What You Need: Organizational Determinants of Diversity Programs." American Sociological Review 76 (3): 386-411.

Downing, Joseph. 2015. "Understanding the (Re)Definition of Nationhood in French Cities: A Case of Multiple States and Multiple Republics." Studies in Ethnicity and Nationalism 15 (2): 336-351.

Eisenberg, Avigail, and Will Kymlicka. 2011. "Bringing Institutions Back In How Public Institutions Assess Lolentity." In Identity Politics in the Public Realm: Bringing Institutions Back In, edited by Avigail Eisenberg and Will Kymlicka, 1-30. Vancouver: UBC Press.

Fassin, Didier. 2002. "L'intervention Française de la Discrimination." Revue française de science politique 52 (4): 403-423.

Flamant, Anouk. 2017. "L'incomplète construction des politiques municipales de lutte contre les discriminations raciales. Enquête dans les villes de Lyon, Nantes et Strasbourg (2001-2012)." Revue Internationale de Politique Comparée 24 (3): 257-292.

Florida, Richard. 2005. Cities and the Creative Class. New York: Routledge.

Frappat, Pierre, and Hubert Dubedout. 2016. Hubert Dubedout, une pensée en action: écrits et discours. Grenoble: Presses Universitaires de Grenoble.

Gastaut, Yvan. 2003. "Marseille cosmopolite après les décolonisations: un enjeu identitaire." Cahiers de la Méditerranée 67: 269-285.

Geisser, Vincent, and Schérazade Kelfaoui. 2001. "Marseille 2001, la communauté réinventée par les politiques." Migrations société 13 (77): 55-77.

Good, Kristin R. 2018. "Municipal Immigration Policymaking in Canadian Cities: The State of the Art 1." In The Routledge Handbook of the Governance of Migration and Diversity in Cities, edited by Tiziana Caponio, Peter Scholten, and Ricard ZapataBarrero, 216-228. New York: Routledge.

Kingdon, John W. (1984) 1995. Agendas, Alternatives, and Public Policies. Boston: Little, Brown. 
Le Galès, Patrick. 2001. “Urban Governance and Policy Networks: On the Urban Political Boundedness of Policy Networks. A French Case Study." Public Administration 79 (1): 167-184.

Lorcerie, Francoise, and Vincent Geisser. 2011. Muslims in Marseille. New York: Open Society Foundations.

Martínez-Ariño, Julia. 2018. "Conceptualising the Role of Cities in the Governance of Religious Diversity in Europe." Current Sociology 66 (5): 810-827.

Martínez-Ariño, J., M. Moutselos, K. Schönwälder, C. Jacobs, M. Schiller, and A. Tandé. 2019. "Why Do Some Cities Adopt More Diversity Policies Than Others? A Study in France and Germany." Comparative European Politics 17 (5): 651-672.

Mattina, Cesare. 2016. Clientélismes urbains: gouvernement et hégémonie politique à Marseille. Paris: Presses de Sciences Po.

Mintrom, Michael, and Phillipa Norman. 2009. "Policy Entrepreneurship and Policy Change." Policy Studies Journal 37 (4): 649-667.

Mitchell, Katharyne. 2011. "Marseille's Not for Burning: Comparative Networks of Integration and Exclusion in Two French Cities." Annals of the Association of American Geographers 101 (2): 404-423.

Moore, Damian. 2001. "Marseille: Institutional Links with Ethnic Minorities and the French Republican Model." In Multicultural Policies and Modes of Citizenship in European Cities, edited by Alisdair Rogers, and Jean Tillie, 123-141. Aldershot: Ashgate.

Moutselos, Michalis, Christian Jacobs, Julia Martínez-Ariño, Maria Schiller, Karen Schönwälder, and Alexandre Tandé. 2020. "Economy or Justice? How Urban Actors Respond to Diversity." Urban Affairs Review 56 (1): 228-253.

Page, Scott E. 2007. The Difference: How the Power of Diversity Creates Better Groups, Firms, Schools, and Societies. Princeton: Princeton University Press.

Penninx, Rinus. 2015. "European Cities in Search of Knowledge for Their Integration Policies." In Integrating Immigrants in Europe, edited by Peter Scholten, Han Entzinger, Rinus Penninx, and Stijn Verbeek, 99-115. Cham: Springer.

Peraldi, Michel, and Michel Samson. 2013. Gouverner Marseille: enquête sur les mondes politiques marseillais. Paris: La découverte.

Pierce, Jonathan J., Holly L. Peterson, Michael D. Jones, Samantha P. Garrard, and Theresa Vu. 2017. "There and Back Again: A Tale of the Advocacy Coalition Framework." Policy Studies Journal 45 (S1): S13-S46.

Rohlfing, Ingo. 2012. Case Studies and Causal Inference: An Integrative Framework. Basingstoke: Palgrave Macmillan.

Sabatier, Paul A., and Christopher M. Weible. 2007. "The Advocacy Coalition Framework." Theories of the Policy Process, edited by Paul A. Sabatier, 189-220. Boulder, CO: Westview.

Schiller, Maria. 2015. "Paradigmatic Pragmatism and the Politics of Diversity." Ethnic and Racial Studies 38 (7): 1120-1136.

Sénac, Réjane. 2012. L'invention française de la diversité. Paris: Presses Universitaires de France.

Simon, Patrick, and Valérie Sala Pala. 2010. "'We Are Not All Multiculturalist Yet': France Swings Between Hard Integration and Soft Antidiscrimination." In The Multiculturalist Backlash. European Discourses, Policies and Practices, edited by Steven Vertovec, und Susanne Wessendorf, 92-111. London: Routledge.

Vertovec, Steven. 2012. "Diversity' and the Social Imaginary." European Journal of Sociology/Archives Européennes de Sociologie 53 (3): 287-312.

Vigouroux, Robert. 1991. Un parmi les autres. Paris: Albin Michel. 
Ville de Marseille. 2006. "Lancement official de la Candidature de Marseille-Provence, Capitale Européenne de la Culture 2013." Dossier de Presse, December 14.

White, Bob W., ed. 2017. Intercultural Cities: Policy and Practice for a New Era. London: Springer.

Zapata-Barrero, Ricard, and Ted Cantle. 2018. "City Governance of Migration and Diversity: Interculturalism as a City Policy Paradigm." In The Routledge Handbook of the Governance of Migration and Diversity in Cities, edited by Tiziana Caponio, Peter Scholten, and Ricard Zapata-Barrero, 193-203. New York: Routledge. 